\title{
INTERACTION OF HISTORY WITH THE ALBANIANS' LITERARY TRADITION
}

\section{Farida MAMMADOVA}

: https://orcid.org/0000-0002-2007-5240

Azerbaijan National Academy of Sciences (ANAS), Azerbaijan

\section{ABSTRACT}

The term "history of literature" itself we see the historical development of a literature, the literary progression of a nation, and beyond, to other levels up to the world literature. Despite the barriers and directions of ideologically dictated interpretations, Albanian literature moves on and develops, i.e. stands out and grows outside the claimed frames. Along with its development, numerous valuable studies of the process of drafting a new history of literature are also underway. Literature is in permanent communication with texts of history. In this way, history and literature help each other. The Albanian language was a language spoken in the territory of the old Christian state Albany or Albania that was situated in the territory of modern Azerbaijan and was known already before the adoption of Christianity. The Albanian historical and literary tradition began to take shape in the 5 th century and was further developing during the 5 th -13 th centuries.

The paper presents that the formation of Albanian literature in the Albanian language was an objective $\urcorner$ historical necessity.

\section{ARTICLE INFO}

\section{ARTICLE HISTORY}

Received:

21 November, 2020

Accepted:

12 February , 2021

Published:

25 April, 2021

Available online:

25 April, 2021

\section{KEYWORDS}

Albania, literary tradition, writing system, historical development, Albanian language 


\section{Introduction}

Albanian historical and literary tradition includes hagiographic, church-based and legal, secular literature, and historical chronicles. The material studied proves that the formation of Albanian literature in the Albanian language was an objective historical necessity. The change in literature is marked by its value, and the literary discourse of change produces the change in the established system. Albania was prepared for the creation of its literature by socio-economic, confessional and political conditions. This was the time of an independent Albanian state with the ruling royal dynasty of Arsacids and the great Mihranid princes who replaced them, along with the Albanian Apostolic Autocephalous Church. Albanian literature can be subdivided into three successive branches: Syrophilic, Gree cophilic, and Albanian.

The Albanian literature has been created as every literature created within a specific system and within codes and different historical circumstances, which are turned into essential elements in the thinking for literature. This approach of reading and interpretation of literature as a form of influence in writing and learning of history, as a content, and as a model, in history is sensitive. Numerous scholars of the Albanian literature, support the fact that history became a distinct and influential literary school within the Albanian literature until the modern time. Nowadays, it is usually called Caucasian Albania in order to differentiate it from the Balkan Albania.

\section{History of the Albanian Writing system}

Albanian spoken in the Caucasus belonged to the Caucasian languages, in particular, to the Lezgian group of the North-East Caucasian languages. Among the languages spoken today, the closest related language of Albanian is Udi, spoken in some villages of Azerbaijan and Georgia. Writing and literature in the Albanian language, one of the North-East Caucasian (Nakh-Dagestanian) languages, were formed in connection with Christianization of the country. Christianization was to a great extent facilitated by the Albanian alphabet (containing 52 letters) and the Albanian writing system created in the middle of the 4th century and based on the Proto-Udi language used to translate the Bible and other theological literature from the Syrian and Greek languages into Albanian. 
This is evidenced by the Georgian-Albanian rescript (M/8T-13, M/5ш-50) found in 1996 in the monastery of St. Catherine on Mount Sinai by Associate Member of Georgian National Academy of Sciences Z.N. Aleksidze. On the 26th of May 1975 a collection of Georgian manuscripts were discovered on Mount Sinai in Palestine. Expeditions to Mount Sinai were arranged in 1990-2000 by the Institute of Manuscripts of the Georgian Academy of Sciences in order to study the collection. This turned out to be the decisive fact for the discovery and deciphering of the Albanian texts. In some palimpsests (manuscripts where the new text is written over the old text) the old text turned out to be Albanian.The Albanian language was a language spoken in the territory of the old Christian state Albany or Albania that was situated in the territory of modern Azerbaijan and was known already before the adoption of Christianity. Nowadays, it is usually called Caucasian Albania in order to differentiate it from the Balkan Albania.As can be seen, as early as in the 4th century the Albans had a complete translation of the Bible and the Lectionary created by them in Albanian (Алексидзе, 2002).

Historians suggest that the disappearance of the Albanian state and its written script occurred over several centuries due to various political influences in the region. First came the Arabian invasion and the process of Islamization (7-10th centuries) followed by the invasion of Turk-Seljuks and assimilation with them (11th century). The fact that Albanian writing was used in the 14th century is reported by historian Hayton of Corycus (Hethum the Historian) (from the Hetumid family hailed from Ganja), living in Cilicia, in his book "La flor des estoires de la terre d'Orient" ("Flower of the Histories of the East"), written in 1307 in Old French: "... there were different alphabets - one Armenian, the other Albanian" (I, гл. IX) (Мамедова, 2005).

\section{Albanian Literature: A Short History}

Basic historical information about Albania in the 1st - 10th cc. is provided by the outstanding representative of the historical and literary tradition, the Albanian author Movses Kaghankatvatsi and his successor in the "History of the Albanians", which has come down to us in the Old - Armenian language, translated from Albanian. Examination of the handwritten basis of the "History of the Albanians" by Movses-Kaghankatvatsi, study of the genealogy of the manuscript lists of the " History of the Albanians" allowed drawing a genealogical tree of the source manuscripts, which is divided into two groups according to the discrepancy there of: 
1) One that underwent purposeful editing by the Armenian Church,

2) One that did not undergo editing.

The study was based on the analysis of all existing editions of the "History of the Albanians" - three Old Armenian, a modern Armenian, English and Russian and involved four additional manuscripts from St. Petersburg and the National Library of France, of which two belong to the Albanian edition in the context of discrepancy (J10 ИВАН S-59 and Р4 220) and two to the Armenian edition (ЛО ИВАН В-56 и Рі 217 (Makler catalogue), (Мамедова, 1982).

This work revealed that the Armenian Church, in order to annex the Albanian historical and literary heritage, edited to a great extent one manuscript of Kaghankatvatsi's "History of the Albanians" in the interests of the history of the Armenian Church when translating it into the Old Armenian language and introduced into scientific use this edited version and copies from it, which formed the basis of all the existing editions of the "History of the Albanians" by -Kaghankatvatsi, as well as the basis of all studies of Orientalists, Caucasian scholars, everyone who was interested in this Albanian written source (Каланкатуйский, 1861; C.J.F.Dowsett, The History of the Caucasian Albanians by Movses Dasxuranci, 1961). The editing was aimed at giving Armenian origin to the Albanian rulers, the entire history of the country, the subordination of the Albanian Church.

Equally important was the revelation of the editing of the acrostic Elegy of the Albanian poet Davtak, written on the death of the Great Prince Javanshir and originally covering 19 letters of the Albanian alphabet. However, in course of translation and Armenian editing, the acrostic was deliberately dragged out covering all the 36 letters of the Armenian alphabet. Nevertheless, several manuscripts have survived, translated into Armenian without being edited. The textual analysis of these two groups of manuscripts indicates fundamental differences in them. The textual analysis, examination of the style of writing, the chronological system of dating the events in the "History of the Albanians" show that the content of the "History of the Albanians" (which describes the history of Albania from ancient times to the beginning of the VIII century: the history of the Albanian ethnos, the rulers of the country, the Albanian Church, where the territorial boundaries of the country are outlined three times, in different periods stably located on two banks of the Kura River, etc.), the manner of presentation, the author's attitude to the events and individual historical figures (Catholicos Viro, Vachagan III, Javanshir, poet Davtak), the strictly developed chronological system of the author, i.e. dating events on the basis of the rule of the Albanian rulers, as well as the rule of the Persian and Byzantine kings (dating with synchronization) gives grounds for the only conclusion 
that the "History of the Albanians" was written by an Albanian for the Albanian people: books I and II - at the beginning of the 8th century, and book III - in the 10th century. (Мамедова, 1977); (Мамедова, 1986), (Мамедова, 2005).

The chronicle of the Albanian Catholicos Viro and the Elegy "On the death of the great Albanian prince Javanshir" by the Albanian poet Davtak are examples of hagiographic literature of the 5 th -8 th centuries.

Studies have shown that the period of 11-13 cc. was the heyday of the Albanian written heritage. It was during this period that the role of Ganja rises. It was the center of the Albanian Christian and Muslim renaissance, which gave such famous representatives of Albanian historiography as David Alavik, Mkhitar Gosh ("The Albanian Chronicle", "The Lawcode") (Гош Мхитар, 1960), Kirakos Gandzaketsi ("History") (Гандзакеци Киракос, 1946), Vardan the Great Aghvanetsi / the Albanian ("General History"), Gregory Patmich-Magakiya ("The History of the Mongols"), Smbat Sparapet, Hayton of Corycus ("Flower of the Histories of the East"), whose invaluable works reflected certain aspects of Albanian society, its political and spiritual life. Their works highlighted the political events of the 11th - 13th centuries, the period of Seljuk and Mongol domination in the Caucasus and Western Asia, and also preserved valuable information about the history of Georgia, Armenia, Byzantium, Cilicia, the history of Christianity in general and the Albanian Apostolic Autocephalous Church in particular.

Studying the works of Mkhitar Gosh and Kirakos Gandzaketsi has led to the conviction that when translated from Albanian into Old Armenian, these works also underwent purposeful "editing", when Gosh's "Lawcode" was turned into "The Armenian Lawcode", and "The History" by Kirakos Gandzaketsi into "The History of Armenia". Attempts were made to bring the text of Kirakos in line with the new title.

Certain editing was also made to the work of Hayton of Corycus (an author of the 13-14th centuries), a descendant from the royal family of the Albanian Hethumids who ruled Cilicia from 1226 to 1342. M. Avgerian, in his translation of Hayton of Corycus' work into the Old Armenian language, skipped whole fragments of the text at his discretion.

A study showed that during the rise of Albanian literature in the 11-13th centuries, associated with the general political, economic and cultural revival of the local Albanian kingdoms (in Syunik, Karabakh-Artsakh, Shaki-Kambisen), in Armenian political, cultural life and, accordingly, in literature there was a decline. 
This is accounted for by the forcible resettlement policy of Byzantium in relation to the Armenians and the Seljuk invasions, as well as the policy of the Armenian feudal nobility who strived to gain titles, positions, lands from the rulers, to whom the interests of the Armenian people were sacrificed. This is the reason why the Armenians lost their statehood.

We should also note the work of the author of the 13th c. Stepannos of Syunik "The History of the Sisakan Clan", which allows to highlight important historical moments from the history of the Albanian province of Syunik (Сюнийский Степаннос, 1861).

The historical and literary tradition continued in subsequent centuries, when in the 18 c. Albanian Catholicos Yesai Gasan-Jalalyan wrote "A Brief History of the Albanian Land (1702-1722)", first published in 1839 in Shusha by the Karabakh Metropolitan Baghdasar Gasan-Jalal. Its second edition was published in Jerusalem in 1868. This work was translated into French by the Member of the Imperial Academy of Sciences M. Brosse and published in St. Petersburg in 1876 (ХасанДжалалян Есаи, 1989).

In the 19 c., bishop Makar Barkhudaryants wrote three works: "Artsakh", "The Country of Albania and Its Neighbors" and "The History of the Country of Aghvank" (Бархударян, 1895, Бархударян, т.I, 1902; т.II, 1907; Бархударян, т.I, 1901; Бархударян, 1893).

It is revealing that all of the authors mentioned, from the 8th to the 19th c., note the Albanian self-awareness, both in the text of the sources and in the very titles of their works.

Albanian legal sources include the canons of the Aguan Cathedral of the 5th century (Мамедова, 1968; Мамедова, 1976, Мамедова, 1976), canons of the Partaw Cathedral of 705, referred to as the canons of the Albanian Catholicos Simeon; canons of David Alavik, "The Lawcode" by Mkhitar Gosh, "The Lawcode" by Smbat Sparapet.

Mkhitar Gosh's "Lawcode" was a source for Smbat Sparapet's "Lawcode". A study showed the wrongfulness and groundlessness of the Armenian concept, according to which the Albanian sources of the 5-13 cc. and the subsequent centuries were declared Armenian, as if originally written in Armenian for the Armenian people. The study of historical realities - the political and confessional 
Armenia and Albania of the same period (5-13th cc.) showed that the Armenian language during the said period could be the lingua franca neither in Albania nor in the Central Caucasus.

According to sources, Armenians appeared in this territory in the late 18th early 19th centuries. The population of Albania was autochthonous, Albanian with constant seepage and settling of Turkic and Persian speaking tribes from the 1st century BC. Before the 14th century, Albanian literature was created in the Albanian language, and later in the Old Armenian language. The study of the history of the Armenian people, the history of the Armenian Church, their juxtaposition with the Albanian realities convince that for the entire period of the Albanian Church (4 c. 1836) it remained independent, monophysite, like the Coptic and Yakobite churches.

Taking into account that the Albans had their own stable territory, political formations (up to the 8th century within Albania from the Aras in the south to Derbent in the north; from the 9th to the 13th cc. - the local kingdoms-principalities in Syunik, Artsakh, Shaki-Kambisen and further from the 15th century- the five Albanian melikdoms), Autocephalous Church, they were surrounded by a Muslim (Turkic and Iranian-speaking) ethnos, when the local Albanian kingdoms (from the 9th to the 15th cc.) were constantly part of the Azerbaijani states, the Albans didn't have to switch to the Armenian language to write their works. Turkic becomes the language of interethnic communication, the lingua franca since the 12th century.

The fact that Albanian literature was preserved in the Old Armenian language was more likely associated with the geopolitical changes that involved the transformation of the Albanian ethnocultural heritage into Armenian, starting with the rethinking of the Albanian historical and literary tradition. After the abolition of the Albanian Apostolic Autocephalous Church in 1836 by Russian tsarist government and its subordination to Etchmiadzin, the Armenian clergy started publishing Albanian literature, having translated it into Armenian and edited with a deeply thought-out Armenian concept.

The information from bishop Barkhudaryants' "Artsakh" is the evidence of the transformation of the Albanian heritage into the Armenian one. But even edited, the Albanian written legacy allowed restoring the chronological sequence of the development of the Albanian historical and literary tradition. 


\section{Conclusion}

This study decodes the authoritative function of Albanian literary history, full of history of socio-political conditions, alongside them with the course of literature and historical development. The most important result in the post-war Albanian culture in terms of the literary development is the unification of the standard Albanian, elaborated to the level of a modern language. In the current stage, Albanian literature is experiencing the advantages of its opening to the world, but also the problems that are faced in such conditions by the culture of any nation to preserve its own identity.The Albanian people were among the last one in Europe to build up their own national community. The expression of common sense of the Albanian national identity was issued by Albanian political leadership in the years of the Balkan Wars 1912-1913 in the following slogan: "Neve Shqiptar nuk jemi Greke, Sllav, or Teerk, neve jemi Shqiptar" ("We Albanians are not the Greeks, Slavs, or Turks, we are the Albanians").

The spectrum of modern Albanian literature is much wider than the availability of existing works, and it is to be hoped that good literary works will soon reflect this diversity. The history of literature is linked to the whole of the facts and does not stop only with great authors and masterpieces, but also with young authors who bring something new, something different.

\section{Disclosure statement}

No potential conflict of interest was reported by the author. 
References and notes:

Алексидзе А. (2002).Что может рассказать об истории церкви Кавказской Албании обнаруженный на Синайской горе грузино-албанский палимпсест (What a Georgian-Albanian rescript found on Mount Sinai can tell about the history of the Caucasian Albanian Church)/ The history of Caucasus. The scientific-public Almanac. №2, s.15-26.

Бархударян М.(1895). Арцах. Историко-географическая характеристика (Historical and Geographical Description). Баку. 461 c. (in Armenian)

Бархударян М. (1907).История Албании (History of Albania), т.I. Вагаршапад, 1902, 224 с; т.II, Тифлис.176 с. (in Armenian)

Бархударян М.(1901). История албанцев (History of Albanians), т.I. Тифлис.с.213 (in Armenian).

Бархударян М.(1893). Страна агванов и их соседи (The Aghvan Land and their Neighbors). Тифлис.с. 302 (in Armenian).

Киракос, Г.(1946). История (The History)/ перевод с древнеарм.яз. Т.Тер-Григорьяна. Баку: Издательство АН Азерб.ССР.с 302

Мхитар, Г(1960). Албанская хроника (Albanian Chronicle)/ предисловие, перевод и комментарии 3.М.Буниятова. Баку: Издательство Академии наук Азерб.ССР,с. 34

Каланкатуйский М.(1861). История агван (The History of Aghvan)/ перевод с армян. К.Патканова. СПб.: типография Императорской Академии наук.с. 376

Мамедова Ф. (1976).Агуэнские каноны - Агуэнский собор (The Aguan Canons - the Aguan Cathedral)// ACE, т.I. c.280-281.

Мамедова Ф.(1968). Агуэнские каноны 487/488 гг. как источник по социально-экономической истории Кавказской Албании (Aguen Canons of 487/488 as a Source on the SocioEconomic History of Caucasian Albania)// Изв. АН Аз. ССР, серия ист., филос. и права. №4, с.27-37.

Мамедова Ф.(1982). Интерпретация новых дополнительных глав парижского списка «Истории албан» Моисея Каланкатуйского в свете эпиграфических данных Гандзасарского храма (Interpretation of the new additional chapters of the Parisian list of the "History of the Albanians" by Movses Kaghankatvatsi in the context of the epigraphic data of the Gandzasar temple)/ Тезисы докл. всесоюзной научной сессии «Актуальные проблемы изучения и создания письменных исторических источников». Тбилиси.с.38-39.

Мамедова Ф.(1977). «История албан» Моисея Каланкатуйского как источник по общественному строю раннесредневековой Албании ("History of the Albanians" by Movses Kaghankatvatsi as a Source on the Social Structure of Early Medieval Albania). Баку: Элм.с.202

Мамедова Ф. (2005).Кавказская Албания и албаны (Сaucasian Albania and Albanians). Баку.с. 800

Мамедова Ф.(1986) Политическая история и историческая география Кавказской Албании (III в. до н.э.- VIII в.н.э.) (Political History and Historical Geography of Caucasian Albania (3 с. ВС - 8 с. AD) ), Баку: Элм.с. 284

Степаннос, С.(1861). История рода Сисакан (The History of the Sisakan Clan)/ перевод с арм. М.Эмина. Москва.с. 249

Есаи, Х.(1989). Краткая история страны Албанской (A Brief History of the Albanian Land (17021722))/ 1702- 1722 гг./ перевод с древнеарм. яз. Т.И.Тер-Григоряна, предисловие и подготовка к изданию академика 3.М.Буниятова, Баку: Элм.с. 48

The History of the Caucasian Albanians by Movses Dasxuranci / translated by C.J.F.Dowsett. (1961). London: Oxfort University press, New York, Toronto, p. 252 